\title{
Efficient production of recombinant parathyroid hormone (rPTH) fragment 1-34 in the methy- lotrophic yeast Hansenula polymorpha
}

\author{
Frank Mueller, MSc; Manal Moussa, MSc; Maria El Ghazaly, MSc; Jan Rohde, PhD; Nicole Bartsch, MSc; Antje \\ Parthier, PhD; Frank Kensy, DrIng
}

\begin{abstract}
Background: Osteoporosis is a bone disease of the elderly that leads to increased risk of fracture. Currently, it affects more than 200 million adults worldwide, placing an enormous economic burden on healthcare providers. Present approved drug treatments of osteoporosis, for example, using bisphosphonates, only reduce bone mineral loss, are variable in prevention of future fractures and can induce serious complications long term. From 2002, availability of the recombinant active, N-terminal 1-34 fragment of human parathyroid hormone 1-34, which directly stimulates bone formation, has provided an alternative, potentially more effective therapeutic agent for treating osteoporosis, especially in its most severe form. We have adopted the methylotrophic yeast strain Hansenula polymorpha (H. polymorpha) for production of recombinant parathyroid hormone (rPTH) 1-34 since its expression system is highly inducible and target proteins are secreted intact into the fermentation broth without the need for enzymatic cleavage of a fusion protein.

Methods: Culture conditions for the growth of selected clones of $H$. polymorpha super-transformants and their rPTH production capacity were sequentially optimized through the microtitre plate, shake flask, small tank bioreactor scales to the large bioreactor scale.

Results: The production of rPTH 1-34 by transformed $H$. polymorpha was greatly enhanced by adding the calnexin chaperone gene to the expression plasmid. Implementation of final optimized culture medium constituents and operational fermentation conditions, of which maintenance of constant oxygen tension $\left(\mathrm{pO}_{2}\right)$ was found to be a critical factor at the 80 litre scale, resulted in yields up to $150 \mathrm{mg}$ active $\mathrm{rPTH}$ 1-34 per liter of culture supernatant.

Conclusion: A robust fermentation process for the efficient production of active rPTH 1-34 based on a calnexin super-transformed H. polymorpha clone was developed. Potentially, this has cost-saving benefits for the production and marketing of clinical-grade rPTH $1-34$.
\end{abstract}

Keywords: Hansenula polymorpha, fermentation, parathyroid hormone fragment, recombinant protein, rPTH 1-34

\section{Introduction}

Currently, worldwide there are over 200 million people affected by osteoporosis, a bone disease mainly of the elderly, particularly postmenopausal women, in which increasing porosity of bone structure through mineral loss significantly heightens risk of skeletal fractures [1]. It has proven difficult to prevent or treat effectively and is a major cause of morbidity and hospital admissions, with severe medical and financial burdens on healthcare systems and society as a whole. Osteoporosis-related bone loss occurs when osteoclast-mediated bone resorption exceeds osteoblast-mediated bone formation. Drugs that are approved, such as the widely prescribed bisphosphonates, work by reducing bone resorption.

However, these are mainly administered to patients who have already had fractures, as a preventative measure against further fractures, and are not without risks of complications with longterm usage [2]. Beneficial effects have also been achieved with salmon calcitonin, a hormone that inhibits osteoclast function and increases bone deposition, but it is now less recommended due to its questionable effect on fracture risk and the associated risk of cancer with its prolonged use [3]. In contrast, human parathyroid hormone (hPTH), a polypeptide of 84 amino acids secreted by the parathyroid gland, normalizes serum $\mathrm{Ca}^{2+}$ levels by increasing $\mathrm{Ca}^{2+}$ re-absorption in the kidney and stimulating the osteoclast- and osteocyte-mediated $\mathrm{Ca}^{2+}$ release from bone [4]. This hormone plays a major role in normal bone homeostasis and remodelling, on the one hand by boosting osteoblastogenesis leading to bone formation and on the other hand by indirectly boosting osteoclastogenesis and bone resorption [4]. However, in vivo studies have shown that intermittent short exposure to recombinant human PTH (rhPTH) favoured anabolic bone formation responses over catabolic bone resorption. These led to the development and marketing of rhPTH as an anabolic drug for the treatment of osteoporosis [5-7]. Both rhPTH (Preotact ${ }^{\circledR}$ ) and a recombinant PTH fragment comprising the biologically active N-terminal amino acids 1-34 (rPTH 1-34; teriparatide, Forsteo ${ }^{\circledR} /$ Forteo $^{\circledR}$ ) have proven to be safe and clinically efficacious in osteoporosis patients, especially postmenopausal women [8], though the 'side effect profile' favours rPTH 1-34 [9]. These rPTH products are presently expressed in and manufactured from bacterial (E. coli) and marketed at relatively high costs, approximately Euros 11,000/US $\$ 14,000$ per 24 months of treatment/therapy in Europe and the US. Thus, there is a clear need for developing more efficient expression and production processes for rhPTH or rPTH 1-34 in order that they may be manufactured more cheaply.

\footnotetext{
Author for correspondence: Frank Mueller, MSc, Minapharm Pharmaceuticals, Mina Street, 3rd Industrial Zone A2, 10th of Ramadan City, Cairo, Egypt
}

Submitted: 3 June 2013; Revised: 31 July 2013; Accepted: 2 August 2013; Published online first: 16 August 2013 
The methylotrophic yeast Hansenula polymorpha (H. polymorpha; Pichia angusta) has been successfully developed as an alternative expression system to bacterial ones for heterologous protein production. $H$. polymorpha is able to utilize methanol as sole carbon source, resulting in over-expression of methanol utilization enzymes, namely methanol oxidase (MOX) and formate dehydrogenase (FMD), the expression of which reach up to $70 \%$ of total protein content of cells [10]. Heterologous DNA can readily be integrated via established techniques into the H. polymorpha genome. Such transformations result in high copy, gene numbers stably integrated in the yeast genome, thereby leading on induction to high gene expression and correspondingly high target protein concentrations. The strongly inducible promoters of MOX and FMD genes can be used as regulatory components of heterologous DNA that are inducible via culture medium constituents for target protein gene expression [14, 15].

Furthermore, insertion of the Saccharomyces cerevisiae (S. cerevisiae) derived MF1 leader sequence into the expression cassette enables secretion of the target protein from $H$. polymorpha cells, allowing for an easy recovery of target protein from the fermentation broth [11-13, 16-21]. H. polymorpha transformants have already been utilized in several commercial production processes for the manufacture of recombinant proteins, including interferon- $\alpha 2 \mathrm{a}$ (Reiferon 3 \& 6 MIU and Reiferon Retard, Minapharm Pharmaceuticals), Hirudin (Thrombexx and Extrauma, Minapharm Pharmaceucticals), Insulin (Wosulin, Wockardt), hepatitis B vaccine (Hepavax-Gene, Crucell) and other products in clinical development. Thus, the characteristics of the $H$. polymorpha expression and production system, in which stable heterologous gene expression and synthesis and secretion of recombinant proteins in high quantities are combined, make it suitable for developing a production process for rPTH 1-34 manufacture. In this study, we describe the development of a recombinant supertransformant $H$. polymorpha strain containing the DNA-sequence coding for rPTH 1-34 and extra copies of the $H$. polymorpha calnexin (HPCNE1) gene to enhance the secretion of expressed rPTH 1-34. Optimization of rPTH 1-34 expression by manipulation of medium constituents and cultivation conditions in microtiter plates (1 $\mathrm{mL}$ scale) and shake flasks (300 mL scale), as well as using an automated DASGIP parallel fermenter system, is described. Further details of the transfer of defined/optimized cultivation conditions and scale-up in successive $2,8 \mathrm{~L}$ and $80 \mathrm{~L}$ fermenter systems, in which an intermittent feeding strategy was additionally implemented leading to productivity levels of up to $150 \mathrm{mg} / \mathrm{L}$ of intact and active rPTH 1-34 into the culture broth, are provided.

\section{Material and methods \\ Gene constructs, expression plasmids and generation of $H$. polymorpha strains secreting rPTH 1-34}

H. polymorpha strains secreting rPTH 1-34 were initially generated in wild-type and protease knockout mutants of $H$. polymorpha KLA8-1. The highest amount of rPTH 1-34 was secreted by strains deficient in protease HPYPS7 (KLA8-1/DYPS7). The best of these strains, KLA8$1 / \Delta$ YPS7-MFa-PTH 14-11, secreted up to $700 \mu \mathrm{g}$ rPTH 1-34/L of culture supernatant at the shake-flask scale, as determined with a commercially available ELISA kit (Immutopics International, San Clemente, CA, USA).

It was previously reported that over-expression of the endoplasmic reticulum chaperone calnexin enhances the export and secretion of recombinant proteins in $H$. polymorpha [13]. Subsequently, this finding has been confirmed by Artes Biotechnology GmbH (Langenfeld, Germany) with numerous other products. With the aim of improving secretion and enhancing yields of hPTH, extra copies of the HPCNE1 gene were introduced into the strain KLA8-1/DYPS7-MFa-PTH 14-11 (henceforth termed PTH 14-11), by super-transformation with an HPCNE1 expression cassette. The latter was incorporated in a plasmid that contains a phleomycin resistance gene as a selectable transformation marker. Phleomycin sensitivity of PTH 14-11 was tested prior to super-transformation, and lethality found to lie between $60 \mu \mathrm{g} / \mathrm{mL}$ and $70 \mu \mathrm{g} / \mathrm{mL}$.

Electro-competent PTH 14-11 cells were super-transformed with plasmid HCNE-Phleo(d) which contains the HPCNE1 expression cassette, see Figure 1 for maps of the two plasmids used.

After electroporation, phleomycin-resistant transformant colonies were selected on YPD (yeast extract peptone dextrose) plates containing $70 \mu \mathrm{g} / \mathrm{mL}$ phleomycin. Growing colonies were picked for passaging, a procedure that promotes plasmid proliferation and integration. Three passages in selective and two passages in non-selective medium (YPD) were followed by another cultivation in selective medium. Finally, the cultures

\section{Figure 1: Depiction of the two plasmids used for transformation of $H$. polymorpha}
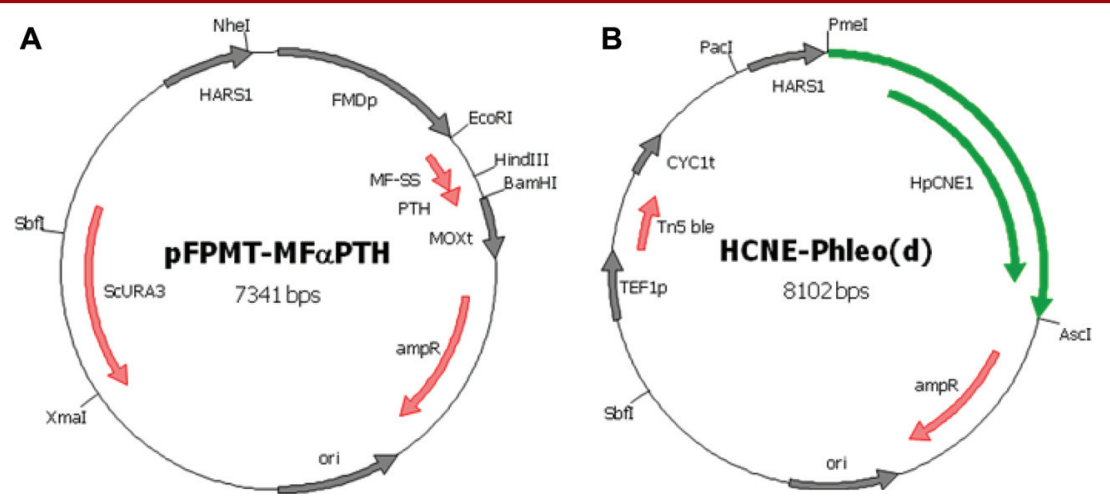

The plasmid maps were generated using Clone Manager (Sci-Ed Software Central, version 7.0).

[A] pFPMT-MF $\alpha$ PTH plasmid contains the coding region for PTH. It is fused with the MF $\alpha$ signal sequence responsible for the secretion of the target protein. FMD-P is a strong promoter activated in presence of methanol from H. polymorpha and MOX-T is the terminator, ScURA3 and ampR are selection markers that enable the identification of positive clones. HARS1 denotes an autonomously replicating sequence from H. polymorpha; ori denotes origin for replication in E. coli. [B] Map of the phleomycin-resistance plasmid introduced into strain KLA8-1/ $\triangle$ YPS7-MFo-PTH 14-11 (PTH 14-11). The calnexin expression cassette in plasmid HCNE-Phleo(d) consists of the HPCNE1 open reading frame and flanking upstream and downstream genomic regions (highlighted in green). The phleomycin-resistance marker is composed of the S. cerevisiae TEF1 promoter, the open reading frame of E. coli Tn5 ble, and the S. cerevisiae CYC1 terminator. HARS1 denotes an $H$. polymorpha autonomously replicating sequence. The elements ampR and ori are required for $E$. coli cloning of the plasmids. 
were streaked on minimal medium without uracil (YNB-glucose) to select for the cells that retained the originally transformed rPTH 1-34 expression plasmids.

The super-transformants were designated KLA8-1/DYPS7-MFaPTH-HCNE or KLA8-1/DYPS7-MFa-PTH-Phleo, abbreviated to PTH-HCNE and PTH-Phleo, respectively, and suffixed with the culture number.

Suitable culture conditions had been established in the preceding rPTH 1-34 expression study. These involved growth in complex medium with $2 \%$ glycerol as the carbon source (YPG - yeast extract peptone glycerol). Fifty $\mu \mathrm{L}$ of concentrated 'overnight' pre-cultures were inoculated in $3 \mathrm{~mL}$ YPG medium in culture tubes and incubated in an orbital shaker at $180 \mathrm{rpm}$ and $37^{\circ} \mathrm{C}$ for $40 \mathrm{~h}$. Cell density was determined by measuring the $\mathrm{OD}_{600}$ of diluted cultures in an Amersham Ultrospec 6300 pro spectrophotometer (GE Healthcare). Cells were removed by centrifugation and cell-free culture supernatants screened for rPTH 1-34 in an 'in-house', sandwich ELISA that utilized two commercial antibodies specific for rPTH 1-34 (Bachem; Torrance, CA, USA, and Biotrend GmbH; Germany) and hPTH 1-34 (Bachem; Torrance, CA, USA) for calibration purposes.

\section{Micro-scale fermentation and rPTH 1-34 production scale- up studies \\ Microtiter plate and shake flask studies}

Initially, investigations were performed with a BioLector (m2p-Labs $\mathrm{GmbH}$; Baesweiler, Germany) micro-fermentation flower-plate system, a flower shaped 48-well microtiter plate with improved oxygen transfer capacity, at $0.5-1.5 \mathrm{~mL}$ scale. The microtiter plates were sealed by a gas permeable membrane (Abgene: AB-0718).

Based on the findings from medium screening in microtiter plates, process parameters and possible feeding strategies were further optimized. This led to the formulation of Syn6-cp medium, which is the standard Syn 6 medium with additional citrate and peptone supplements [12]. Fermentations at the ' $100 \mathrm{~mL}$ scale' used baffled $500 \mathrm{~mL}$ shake flasks and were performed at 180 $\mathrm{rpm}$ for $60 \mathrm{~h}$ at $30^{\circ} \mathrm{C}$ in a shake incubator (New Brunswick Innova 44; Enfield, CT, USA). Wheat peptone (Organotechnie; La Courneuve, France) was compared to soy peptone (Merck; Darmstadt, Germany) and the optimum $\mathrm{pH}$ range for maximum rPTH 1-34 yield determined.

In a fed-batch mode, further optimization of the culture medium with addition of yeast extract (Organotechnie) was carried out in shake flasks. In $250 \mathrm{~mL}$ baffled flasks with a working volume of $50 \mathrm{ml}$, an induction solution containing 10\% methanol, 10\% glycerol and 20\% wheat peptone was added to the culture batch-wise at a rate of $5 \mathrm{~mL}$ feed per $50 \mathrm{~mL}$ culture medium after 20 h, 24 h, 42 h, 46 h, 50 h and 67 h of fermentation. Flasks were shaken at $30^{\circ} \mathrm{C}$ and $180 \mathrm{rpm}$ for 72 hours. Samples were taken 2-3 times daily for $\mathrm{OD}_{600}$, rPTH $1-34$ and $\mathrm{pH}$ measurement. rPTH 1-34 concentration was quantified using RP-HPLC.

\section{Fed-batch studies in bioreactors}

DASGIP parallel stirred $400 \mathrm{~mL}$ tank bioreactors (DASGIP AG; Juelich, Germany) with a maximum working volume of $300 \mathrm{~mL}$ were used for fed-batch process optimization. A 3 L Biostat
B-Plus, a 15 L Biostat C and a 150 L Biostat D (Sartorius Stedim Biotech; Goettingen, Germany) system with working volumes of $2 \mathrm{~L}, 8 \mathrm{~L}$ and $80 \mathrm{~L}$, respectively, were used for scaling up studies and protocol consistency trials.

The culture medium used throughout was synthetic Syn6 medium containing $30 \mathrm{~g} / \mathrm{L}$ glycerol and supplemented with $100 \mathrm{mM}$ citrate, $50 \mathrm{~g} / \mathrm{L}$ wheat peptone and $20 \mathrm{~g} / \mathrm{L}$ yeast extract (Syn6-cp + YE). Its $\mathrm{pH}$ was adjusted with phosphoric acid to 5.7 before steam sterilization for 20 minutes at $121^{\circ} \mathrm{C}$. The inoculate was prepared from a $100 \mathrm{~mL}$ overnight seed culture, which had been cultivated in YPG complex medium in a baffled $500 \mathrm{~mL}$ shake flask at $30^{\circ} \mathrm{C}$. After inoculation, a $24 \mathrm{~h}$ growth phase was followed by an induction phase. During the induction phase a methanol/glycerol/wheat peptone mixture was added in pulses. Different numbers of feed pulses and time intervals between the pulses were evaluated for process optimization. After optimization, pulses were fixed at 4 time points: after $24 \mathrm{~h}, 30 \mathrm{~h}, 36 \mathrm{~h}$ and $42 \mathrm{~h}$ of fermentation. The culture conditions were maintained as follows: unregulated $\mathrm{pH}$ starting 5.7-ending 6.1, aeration rate $3 \mathrm{~L} /$ min decreased after $24 \mathrm{~h}$ to $2 \mathrm{~L} / \mathrm{min}$, stirrer speed $700 \mathrm{rpm}$ and temperature $30^{\circ} \mathrm{C}$.

During the following scale up of fermentation runs to $8 \mathrm{~L}$ and $80 \mathrm{~L}$ scale, certain parameters were optimized to achieve a scalable and reproducible process. The $\mathrm{pO}_{2}$ was regulated at a set point of $30 \%$ saturation by airflow and stirrer speed. The pulse-wise feeding was changed into a feeding schedule with constant feed rates; different feeding schedules were tested. Based on the results obtained, an optimal feeding schedule was achieved and implemented. The feed rate was controlled by using the following program $0 \mathrm{~h}-24 \mathrm{~h}$ batch phase; $24 \mathrm{~h}-27 \mathrm{~h}$ constant feeding with $20 \mathrm{~g} / \mathrm{L} / \mathrm{h} ; 27 \mathrm{~h}-31 \mathrm{~h}$ linear increase up to $60 \mathrm{~g} / \mathrm{L} / \mathrm{h} ; 31 \mathrm{~h}-39 \mathrm{~h}$ constant feeding with $60 \mathrm{~g} / \mathrm{L} / \mathrm{h} ; 39 \mathrm{~h}-39.5 \mathrm{~h}$ constant feeding with $300 \mathrm{~g} / \mathrm{L} / \mathrm{h} ; 39.5 \mathrm{~h}-52 \mathrm{~h}$ constant feeding with $60 \mathrm{~g} / \mathrm{L} / \mathrm{h}$.

The $\mathrm{pH}$ was also controlled such that during the growth phase a constant $\mathrm{pH}$ of 5.5 was maintained to preserve a reasonable growth rate that would result in a cell density $\mathrm{OD}_{600}$ of around 40 at the end of the growth phase. After $24 \mathrm{~h}$ of fermentation, with the beginning of the induction phase, the $\mathrm{pH}$ was increased linearly during $6 \mathrm{~h}$ to a $\mathrm{pH}$ value of 6.1 to promote increased rPTH 1-34 expression, secretion and stability. The temperature was maintained at $30^{\circ} \mathrm{C}$ during the whole fermentation. The total fermentation time was around $52 \mathrm{~h}$, including $24 \mathrm{~h}$ growth phase and subsequent $18 \mathrm{~h}$ induction phase.

The $\mathrm{rPTH}$ 1-34 concentration in samples taken during a fermentation run was measured by RP-HPLC analysis. Cell growth was monitored by optical density measurement and potential contamination was monitored via microscopic examination using a MEIJI light microscope with a 1,000-fold magnifying oil lens. The rPTH 1-34 activity was also measured using a bioassay based on a transformed HEK293 cell line expressing the parathyroid hormone receptor 1 (PTHR1).

\section{Analysis}

\section{Protein analysis by RP-HPLC}

Centrifuged and sterile-filtered aliquots $(100 \mu \mathrm{L})$ of $2 \mathrm{~L}$ fermentation samples and $8 \mathrm{~L}$ and $80 \mathrm{~L}$ fermentation samples were analysed on a Shimadzu LC-2010CHT RP-HPLC- and a 


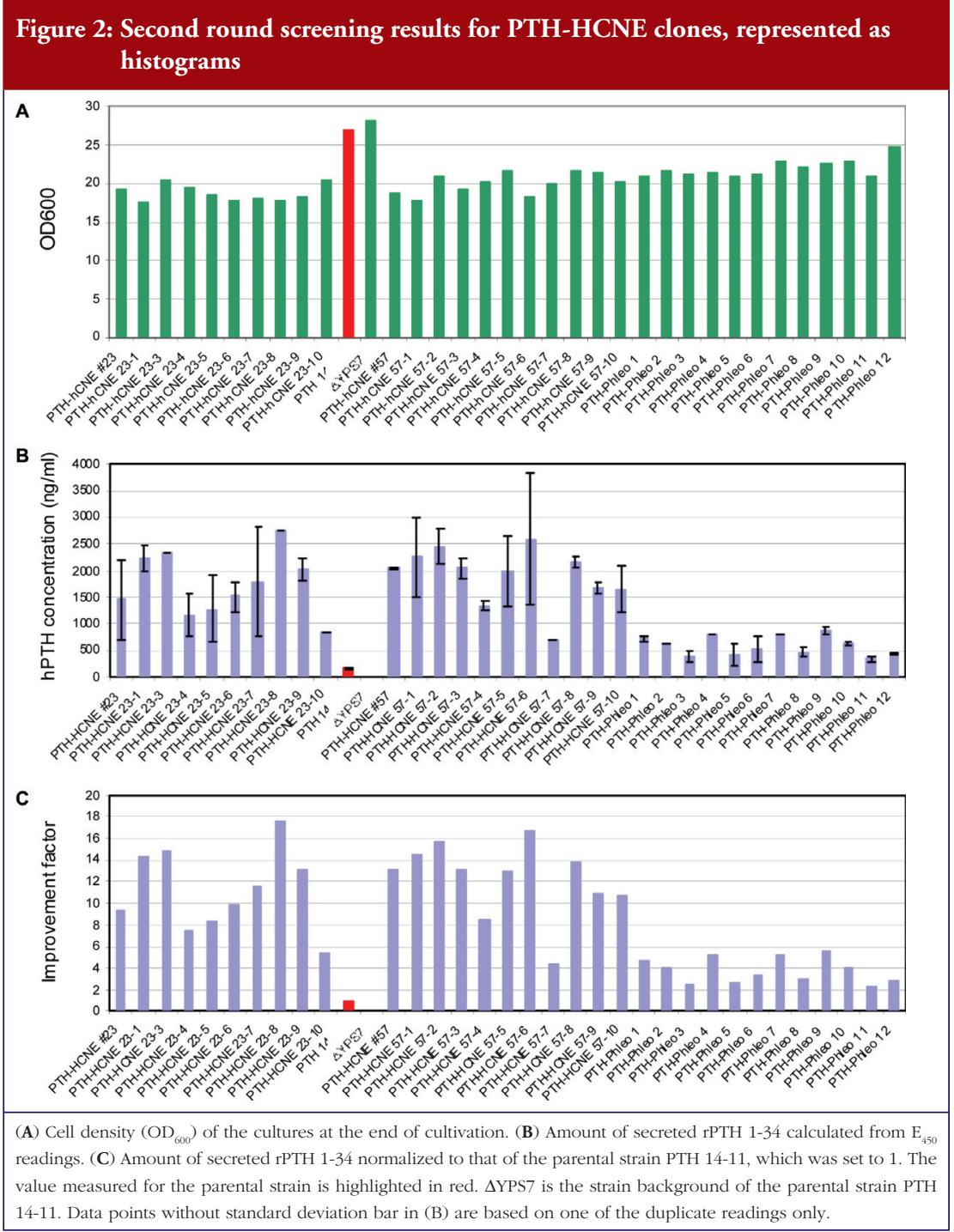

antibody (BT71-6072; Biotrend, 1:466 diluted in $1 \%$ BSA in tris buffered saline).

\section{ELISA}

Initial screen of parental strain before Calnexin insertion was performed using commercially available ELISA kit by a bio-active PTH 1-34-specific ELISA from Immutopics (Immutopics International, San Clemente, CA, USA; Cat. \# 60-3900). The principle of this ELISA is that biotinylated anti-PTH 1-34 antibody bound to rhPTH 1-34 is captured on streptavidin-coated wells, and $\mathrm{rPTH}$ is detected by a horse-radish peroxidase (HRP)-conjugated anti-human PTH 1-34 antibody and quantified by HRP substrate colouration. This ELISA, used for analysing clinical samples, is able to detect hPTH concentrations at the $\mathrm{pg} / \mathrm{mL}$ level. The reference used herein was a synthetic rPTH 1-34 (Bachem, Cat.No. H-4835).

Due to the substantial costs of using the commercial kit, an in-house sandwich ELISA was developed afterwards and used for screening Calnexin super-transformant strain. It was established by coating microtiter plate (NUNC Maxisorb) with Rabbit anti-Parathyroid Hormone 1-34 (human) IgG (Bachem, Torrance, CA, USA) as a capture antibody, followed by blocking using Rotiblock (Roth). Standard hPTH 1-34 (Bachem, Torrance, CA, USA) was serially diluted with phosphate buffered saline (PBS) for calibration curve construction as follows: $500 \mathrm{ng} / \mathrm{mL} ; 250 \mathrm{ng} / \mathrm{mL}$; $125 \mathrm{ng} / \mathrm{mL} ; 62.5 \mathrm{ng} / \mathrm{mL} ; 31.25 \mathrm{ng} / \mathrm{mL} ; 0 \mathrm{ng} / \mathrm{mL}$. Samples were diluted in PBS to lie within the calibration curve range. Standard and samples were adsorbed to the plate. Primary antibody (Mouse anti-human Parathyroid Hormone IgG, Biotrend $\mathrm{GmbH}$ ) and secondary antibody (Goat-anti Mouse HRP Conjugate, BioRad) were applied successively each followed by a wash-

Dionex UltiMate 3000 RS RP-HPLC apparatus, respectively, at a wave-length of $214 \mathrm{~nm}$. Samples were separated on a $5 \mu \mathrm{m}$ Vydac 218TP54 column ( 250 x $4.6 \mathrm{~mm}$; guard column Vydac 218GD54) at a column oven temperature of $25^{\circ} \mathrm{C}$. Elution was performed with a gradient of buffer A $[0.1 \%(\mathrm{v} / \mathrm{v})$ TFA $]$ and buffer $\mathrm{B}[0.1 \%(\mathrm{v} / \mathrm{v}) \mathrm{TFA}$ in acetonitrile], over $26 \mathrm{~min}-$ utes. The flow rate was adjusted to $1 \mathrm{~mL} / \mathrm{min}$. rhPTH $1-34$ content was determined by profile comparison with the World Health Organization-International Standard (WHO IS) of rPTH 1-34 standard of known concentration (04/200—NIBSC; South Mimms, Herts, UK).

\section{Protein analysis by western blot}

Samples were prepared in the same way as for RP-HPLC. Gel electrophoresis was performed using NuPAGE Novex Mini Gels (Life Technologies/Invitrogen) to separate proteins according to their molecular weight. Subsequent blotting was carried out by transferring the proteins onto nitrocellulose membrane where immune-detection was performed using PTH 1-34 specific ing step using $0.05 \%$ Tween 20 in PBS. Finally, development was done using TMB peroxidase substrate (Kirkegaard \& Perry Laboratories, Washington, DC, USA) where reaction is stopped using $1 \mathrm{M}$ phosphoric acid optimally after 2-15 minutes, and developed colour was measured at $450 \mathrm{~nm}$ in Microplate reader (Tecan GENios). Samples were measured in duplicates.

\section{Potency}

Potency of rPTH 1-34 was determined using a cell-based assay (bioassay) developed in cooperation with, and performed at, Bioassay Online, Germany. This bioassay is based on a transformed HEK293 cell line expressing the parathyroid hormone receptor-1 (PTHR1). Stimulation with PTH or rPTH 1-34 at different concentrations leads to concentration-dependent intracellular cyclic adenosine monophosphate (cAMP) formation. Following lysis of cells, the concentration of cAMP is measured with a commercial cAMP kit from Perkin Elmer (Lance Ultra cAMP Kit). WHO IS of rPTH 1-34 (E. coli derived) was used as reference and control, and samples were tested in triplicates. Measurements were made in a time resolved-fluorescence resonance energy transfer 


\section{Table 1: Overview of Syn6-[X] media compositions}

\begin{tabular}{|l|l|l|l|}
\hline Media & Syn6 & Syn6-cp & Syn6-cp+YE \\
\hline Glycerol & $2 \% \mathrm{w} / \mathrm{v}$ & $3 \% \mathrm{w} / \mathrm{v}$ & $3 \% \mathrm{w} / \mathrm{v}$ \\
\hline Salt mix & $10 \% \mathrm{v} / \mathrm{v}$ & $10 \% \mathrm{v} / \mathrm{v}$ & $10 \% \mathrm{v} / \mathrm{v}$ \\
\hline Citrate & - & $100 \mathrm{mM}$ & $100 \mathrm{mM}$ \\
\hline Peptone & - & $5 \% \mathrm{w} / \mathrm{v}$ & $5 \% \mathrm{w} / \mathrm{v}$ \\
\hline Yeast extract & - & - & $2 \% \mathrm{w} / \mathrm{v}$ \\
\hline $\mathrm{CaCl}_{2}$ solution & $1 \% \mathrm{v} / \mathrm{v}$ & $1 \% \mathrm{v} / \mathrm{v}$ & $1 \% \mathrm{v} / \mathrm{v}$ \\
\hline Micro element solution & $1 \% \mathrm{v} / \mathrm{v}$ & $1 \% \mathrm{v} / \mathrm{v}$ & $1 \% \mathrm{v} / \mathrm{v}$ \\
\hline Vitamin solution & $1 \% \mathrm{v} / \mathrm{v}$ & $1 \% \mathrm{v} / \mathrm{v}$ & $1 \% \mathrm{v} / \mathrm{v}$ \\
\hline Trace element solution & $1 \% \mathrm{v} / \mathrm{v}$ & $1 \% \mathrm{v} / \mathrm{v}$ & $1 \% \mathrm{v} / \mathrm{v}$ \\
\hline
\end{tabular}

(TR-FRET) capable plate reader. Readings and data were analysed by Parallel-Line Assay (PLA) 2.0 Software.

\section{Results \\ Strain selection}

Super-transformation with the $H P C N E 1$ gene expression cassette introduced into the parental, $\mathrm{rPTH} 1-34$ producing, strain PTH 14-11 increased secreted yields of rPTH 1-34 by up to 10-fold, with most integrant colonies up by 2- to 4-fold (data not shown). Of 60 integrants, two, PTH-HCNE numbers \#23 and $\# 57$, were found to produce the highest rPTH concentrations and were therefore selected for sub-cloning. At minimum 10 randomly selected single colonies per integrant PTH-HCNE pool, the parent pools, and 12 PTH-Phleo control transformants were screened for rPTH 1-34 expression. Final cell densities of all clones, see Figure 2A, were similar to one another, but the rPTH 1-34 ELISA absorbance values were substantially higher than that of the parental PTH 14-11 strain for all PTH HCNE clones and significantly higher, though less so than PTH HCNE clones, for all PTH-Phleo control transformants, see Figure 2B. Averaged absorbance values across $\# 23$ and $\# 57$ clones were 3-4 times higher ( 2000-2500 ng/mL) than the PTH-Phleo control clone and an average improvement factor of 13-fold when compared to that of the parental strain PTH 14-11, see Figure 2C. We finally chose strain \#23-1 from among the top rPTH 1-34 producers to be taken forward for fermentation development.

\section{Fermentation strategy optimization in a Biolector system}

In this media optimization study, cell growth and protein expression of rPTH 1-34 in all standard media (YPD, YPG, YNB, Syn $6 \mathrm{~N}$ ) and Syn 6-cp media (standard Syn $6 \mathrm{~N}$ media with addition of citrate and peptone), with $\mathrm{pH}$ variations between $\mathrm{pH}$ $4.0-8.0$, were assessed. Table 1 summarizes the compositions of the various Syn 6 media evaluated. Since Syn 6 media tend to precipitation at $\mathrm{pH}$ values higher than 5.0, the Syn 6-cp media contained $100 \mathrm{mM}$ citrate (trisodium citrate) to solubilize all media components at $\mathrm{pH}>5.0$.

Strain \#23-1 expression levels were generally elevated between $\mathrm{pH}$ 5.0-6.0 in all media. The optimal $\mathrm{pH}$ for stable expression of rPTH $1-34$ at $25^{\circ} \mathrm{C}$ or $30^{\circ} \mathrm{C}$ in Syn 6-cp medium was established as 5.3 (starting $\mathrm{pH}$ ). Similar high expression levels were found at both $25^{\circ} \mathrm{C}$ and $30^{\circ} \mathrm{C}$, but fermentation at $30^{\circ} \mathrm{C}$ resulted in much faster cell growth. The latter would lead to a shorter, time saving, process and thus $30^{\circ} \mathrm{C}$ was chosen as the standard fermentation temperature for all subsequent process development experiments. Twenty-one plant peptones (Sigma, Art. No. 11577) and a standard meat gelatone (Merck) as media supplements were screened. In general, cell growth was not much influenced by the peptones, but protein expression varied widely. Three peptones, potato, wheat and soy AX, were found to increase the rPTH 1-34 expression the most (rPTH 1-34 concentration reached was $4.5 \mathrm{mg} / \mathrm{L}$ ) and thus were included in further evaluations. Methanol induction and additional supplementation with $10 \mathrm{~g} / \mathrm{L}$ glycerol and $10 \mathrm{~g} / \mathrm{L}$ peptone (potato, wheat or soy) improved the rPTH 1-34 expression dramatically with increases 8- to 9-fold, i.e. to $\sim 40 \mathrm{mg} / \mathrm{L}$, over the previous levels.

\section{Batch and fed-batch shake flasks}

In $100 \mathrm{~mL}$ scale batch cultures in shake flasks, experiments were performed to compare the three peptones (soy, wheat and potato) at two different concentrations, $30 \mathrm{~g} / \mathrm{L}$ and $50 \mathrm{~g} / \mathrm{L}$, and at starting $\mathrm{pH}$ of 5.0 or 6.0. The highest productivity of $9.6 \mathrm{mg} / \mathrm{L}$ was observed when using the Syn6-cp medium containing $50 \mathrm{~g} / \mathrm{L}$ wheat peptone and $30 \mathrm{~g} / \mathrm{L}$ glycerol at a starting $\mathrm{pH}$ of 6.0 .

In fed-batch $100 \mathrm{~mL}$ cultures in shake flasks, protein expression was induced with a mixture of methanol, glycerol and wheat peptone applied after $20 \mathrm{~h}, 24 \mathrm{~h}, 42 \mathrm{~h}, 46 \mathrm{~h}$ and $50 \mathrm{~h}$ and led to a yield of $25.4 \mathrm{mg} \mathrm{rPTH} 1-34 / \mathrm{L}$. An additional induction pulse at $67 \mathrm{~h}$ had no effect. However, the addition of $20 \mathrm{~g} / \mathrm{L}$ yeast extract to Syn6-cp media (Syn6-cp+YE) almost doubled yield rPTH 1-34 to $48.2 \mathrm{mg} / \mathrm{L}$, see Table 2 .

\section{Scale-up and fermentation consistency $-300 \mathrm{~mL}$ scale in the DASGIP system}

Further steps to optimize productivity were tested in a smallscale $300 \mathrm{~mL}$ parallel bioreactor system under automated and well-controlled fermentation conditions. It was found that four induction pulses were sufficient, starting after $24 \mathrm{~h}$ of cultivation with a time interval of $6 \mathrm{~h}$, to achieve high rPTH 1-34 concentrations. Fermentation was begun at $\mathrm{pH} 5.7$, instead of 6.0, since the lower $\mathrm{pH}$ proved more supportive for initial cell growth. Nevertheless, the $\mathrm{pH}$ increased to 6.1 over the fermentation run. These optimized conditions led to a rPTH 1-34 yield of $68.3 \mathrm{mg} / \mathrm{L}$, around $20 \mathrm{mg} / \mathrm{L}$ greater than achieved with the $100 \mathrm{~mL}$ scale of shake flasks, see Table 2.

\section{$2 \mathrm{~L}$ scale in the Sartorius system}

Conditions that were found best in the $300 \mathrm{~mL}$ production scale were tested and adjusted for maximal rPTH 1-34 yields at the $2 \mathrm{~L}$ scale using a Sartorius bioreactor system. With same medium and induction conditions, only the agitation and aeration rates had to be fine-tuned in accordance with the different geometry and stirring and sparging operations of the larger bioreactor. The total fermentation time was around $50 \mathrm{~h}$, including $24 \mathrm{~h}$ growth phase then $18 \mathrm{~h}$ induction phase. The initial $3 \%$ glycerol in the fermentation medium were consumed by growing cells in the first $24 \mathrm{~h}$, after which a methanol/glycerol/peptone mixture was fed into the medium in four consecutive pulses 


\begin{tabular}{|l|l|l|l|l|}
\hline \multicolumn{2}{|l}{ Table 2: Cultivation in three different cultivation systems and at different scales } \\
\hline Cultivation scale & Medium & $\begin{array}{l}\text { Number } \\
\text { of runs }\end{array}$ & $\begin{array}{l}\text { MeOH } \\
\text { induction } \\
\text { impulses }\end{array}$ & $\begin{array}{l}\text { rPTH 1-34 productivity } \\
\text { (mg/L) }\end{array}$ \\
\hline $\begin{array}{l}\text { Batch culture } 100 \mathrm{~mL} \\
\text { in shake flasks }\end{array}$ & Syn6-cp & several & - & $9.6 \mathrm{mg} / \mathrm{L}$ \\
\hline $\begin{array}{l}\text { Fed-batch culture } \\
100 \mathrm{~mL} \text { in shake flasks }\end{array}$ & Syn6-cp+(YE), pH 6.0 & several & 5 times & $\begin{array}{l}\text { Without YE: } 25.4 \mathrm{mg} / \mathrm{L} \\
\text { With YE: } 48.2 \mathrm{mg} / \mathrm{L}\end{array}$ \\
\hline $300 \mathrm{~mL}$ DASGIP system & Syn6-cp+YE, pH 5.7 & 3 & 4 times & $68.3 \mathrm{mg} / \mathrm{L}$ \\
\hline $\begin{array}{l}\text { 2 L Sartorius system } \\
\text { (before optimization) }\end{array}$ & Syn6-cp+YE, pH 5.7 & 4 & 4 times & $66.8 \mathrm{Nmg} / \mathrm{L}$ \\
\hline 8 L Sartorius system & $\begin{array}{l}\text { Syn6-cp+YE, pH pro- } \\
\text { file: } 5.5 \rightarrow 6.1\end{array}$ & 2 & $\begin{array}{l}\text { Constant } \\
\text { feed profile }\end{array}$ & $120 \mathrm{mg} / \mathrm{L}$ \\
\hline $\begin{array}{l}\text { 80 L Sartorius system } \\
\text { Syn6-cp+YE, pH pro- } \\
\text { file: } 5.5 \rightarrow 6.1\end{array}$ & 1 & $\begin{array}{l}\text { Constant } \\
\text { feed profile }\end{array}$ & $150 \mathrm{mg} / \mathrm{L}$ \\
\hline $\begin{array}{l}\text { 2 L Sartorius system } \\
\text { (after optimization) }\end{array}$ & $\begin{array}{l}\text { Syn6-cp+YE, pH pro- } \\
\text { file: } 5.5 \rightarrow 6.1\end{array}$ & 6 & $\begin{array}{l}\text { Constant } \\
\text { feed profile }\end{array}$ & $150 \mathrm{mg} / \mathrm{L}$ \\
\hline
\end{tabular}

concentrations, see Figure 3b; in three consecutive runs at $8 \mathrm{~L}$ and $80 \mathrm{~L}$ scales.

Retrospectively, the final optimized fermentation protocol applied at the $8 \mathrm{~L}$ and $80 \mathrm{~L}$ scale was transferred to the $2 \mathrm{~L}$ scale and a comparison was performed between the parental strain PTH 14-11 (without insertion of the calnexin gene) and the PTH-HCNE 23-1 clone (with inserted calnexin gene). The results showed that the parental strain PTH 14-11 produced a yield of rPTH of only $32.9 \mathrm{mg} / \mathrm{L}$, while the supertransformant strain PTH-HCNE 23-1 produced $150 \mathrm{mg} / \mathrm{L}$, i.e. a 4-5-fold higher yield with the calnexin gene insertion. This

every $6 \mathrm{~h}$. Culture samples were taken during fermentation and analysed for rPTH 1-34 content and cell density. After fermentation for around $50 \mathrm{~h}$, the entire culture broth was harvested and, following cell removal by centrifugation, the supernatant stored at $-80^{\circ} \mathrm{C}$. The optimized conditions led to consistent and reproducible productivity levels of around $67 \mathrm{mg} / \mathrm{L}$, equivalent to those achieved with the $300 \mathrm{~mL}$ scale, see Table 2.

\section{Fermentation at $8 \mathrm{~L}$ and $80 \mathrm{~L}$ scale}

The optimized conditions defined for the $2 \mathrm{~L}$ scale, as above, were applied to the $8 \mathrm{~L}$ and $80 \mathrm{~L}$ scales. Two fermentations were performed at $8 \mathrm{~L}$ scale and one at $80 \mathrm{~L}$ scale. During these scaled up runs, substrate limitations between feed pulses were observed, which resulted in a sharp increase of the partial oxygen pressure $\left(\mathrm{pO}_{2}\right)$, probably due to higher oxygen transfer at equal stirrer speed compared to the $2 \mathrm{~L}$ scale. To augment production stability for larger scales, certain changes in conditions were successively introduced. Firstly, the $\mathrm{pO}_{2}$ control was set to $30 \%$ saturation. This resulted in higher metabolic activity, which led to higher substrate consumption. Accordingly, it was necessary to modify the feed strategy. However, the higher and constant feed rate negatively impacted on the $\mathrm{pH}$, which fell to 5.2, a value at which rPTH 1-34 stability is reduced. Therefore, a $\mathrm{pH}$ control was introduced as well, see Material and methods.

By implementing these last optimizations of the fermentation conditions, an improvement in rPTH 1-34 concentration from about $60 \mathrm{mg} / \mathrm{L}$ at the $2 \mathrm{~L}$ scale to $120 \mathrm{mg} / \mathrm{L}$ and $150 \mathrm{mg} / \mathrm{L}$ at $8 \mathrm{~L}$ and $80 \mathrm{~L}$ scale, respectively, was attained, see Table 2. Potency determinations of rPTH 1-34 in samples from an $80 \mathrm{~L}$ scale batch (batch number SPM-158-13-D1) in bioassays calibrated with the WHO IS of rPTH 1-34 (specific activity of 10,000 IU/ $\mathrm{mg}$ ) ranged from 9,580-10,920 IU/mg. E.coli derived rPTH 1-34 (Forteo, Eli Lilly) was also tested by this assay as a control and determined potencies ranged from 9,524-10,312 IU/mg. High reproducibility of the optimized fermentation protocol was shown for cell density $\left(\mathrm{OD}_{600}\right)$, see Figure $3 \mathrm{a}$; and $\mathrm{rPTH} 1-34$
rPTH 1-34 yield of $150 \mathrm{mg} / \mathrm{L}$ was successfully reproduced in six consistency runs, see Table 2 .

Graphical representation of the cell density $\left(\mathrm{OD}_{600}\right)$ values at increasing times during fermentation runs at different bioreactor scales shows a high degree of comparability among runs. Maximum $\mathrm{OD}_{600}$ values were about 270 at the end of fermentation runs $(\Delta$ first batch after development at $8 \mathrm{~L}$, second batch after development at $8 \mathrm{~L}, \diamond$ third batch after development at $80 \mathrm{~L}$ ).

Graphical representation of rPTH 1-34 concentrations at increasing times during fermentation runs at different bioreactor scales. Maximum rPTH 1-34 concentrations were about $150 \mathrm{mg} / \mathrm{L}$ at the end of fermentation runs $(\Delta$ first batch after development at $8 \mathrm{~L}$, second batch after development at $8 \mathrm{~L}, \diamond$ third batch after development at $80 \mathrm{~L}$ ).

A typical RP-HPLC profile of a PTH 1-34 fermentation supernatant sample is presented in Figure 4.

\section{Discussion/Conclusion}

In developing high secreting rPTH 1-34 $H$. polymorpha strains, we made advantage of the known protein stabilizing activity of the chaperone calnexin. This molecular chaperone appears to aid folding mechanisms for proteins when entering the endoplasmatic reticulum [19]. Co-expression of calnexin in a rPTH 1-34 producing $H$. polymorpha strain enhanced rPTH 1-34 secretion by about 4- to 5-fold over that of the parental strain. Our results support findings published for other proteins such as manganese peroxidase [20], alginate epimerase, fungal consensus phytase, human IFN- $\gamma$ and human serum albumin [13].

Successful expression of full-length PTH 1-84 or PTH fragments in bacteria or yeasts have been reported elsewhere in the literature [21-35], see Table 3. Many of these have utilized fusion protein' approaches that typically need an enzymatic cleavage 
Figure 3a: Graphical representation of the cell density $\left(\mathrm{OD}_{600}\right)$

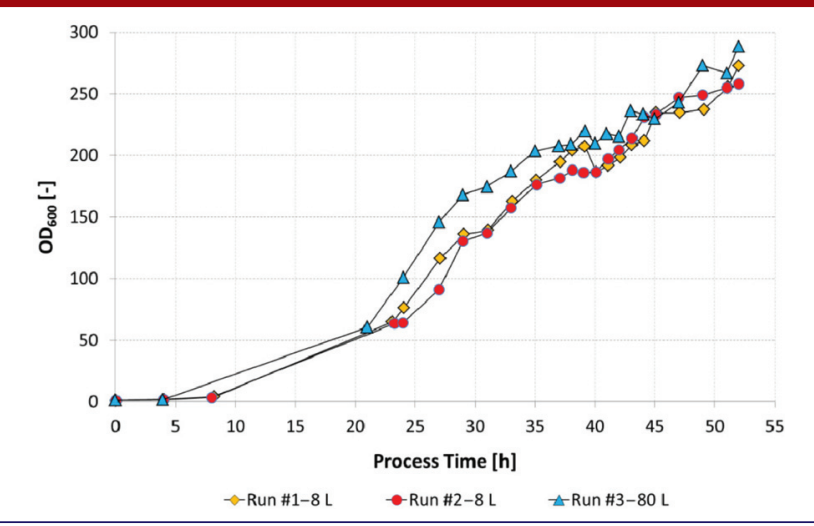

Graphical representation of the cell density $\left(\mathrm{OD}_{600}\right)$ values at increasing times during fermentation runs at different bioreactor scales shows a high degree of comparability among runs. Maximum $\mathrm{OD}_{600}$ values were about 270 at the end of fermentation runs ( $\triangle$ first batch after development at $8 \mathrm{~L}$, $\circ$ second batch after development at $8 \mathrm{~L}, \diamond$ third batch after development at $80 \mathrm{~L}$ ).

Figure 3b: Graphical representation of rPTH 1-34 concentrations

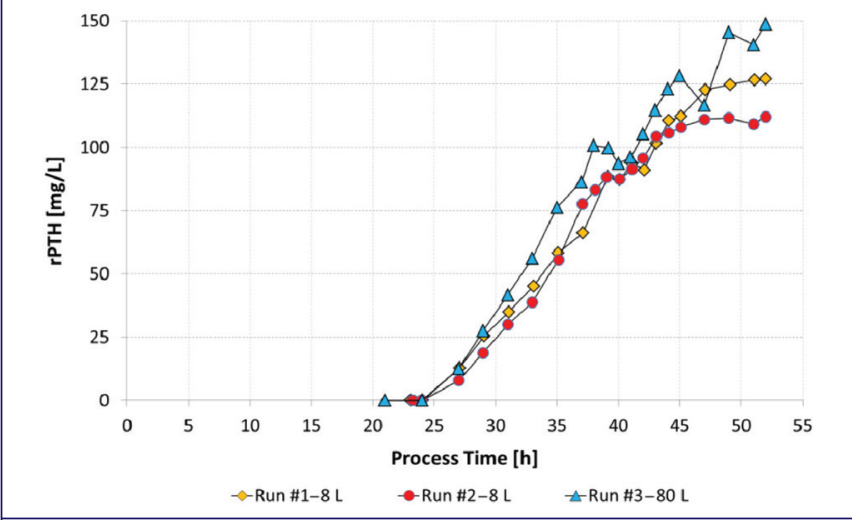

Graphical representation of $\mathrm{rPTH} 1-34$ concentrations at increasing times during fermentation runs at different bioreactor scales. Maximum rPTH 1-34 concentrations were about $150 \mathrm{mg} / \mathrm{L}$ at the end of fermentation runs ( $\triangle$ first batch after development at $8 \mathrm{~L}$, $\circ$ second batch after development at $8 \mathrm{~L}, \diamond$ third batch after development at $80 \mathrm{~L}$ ).

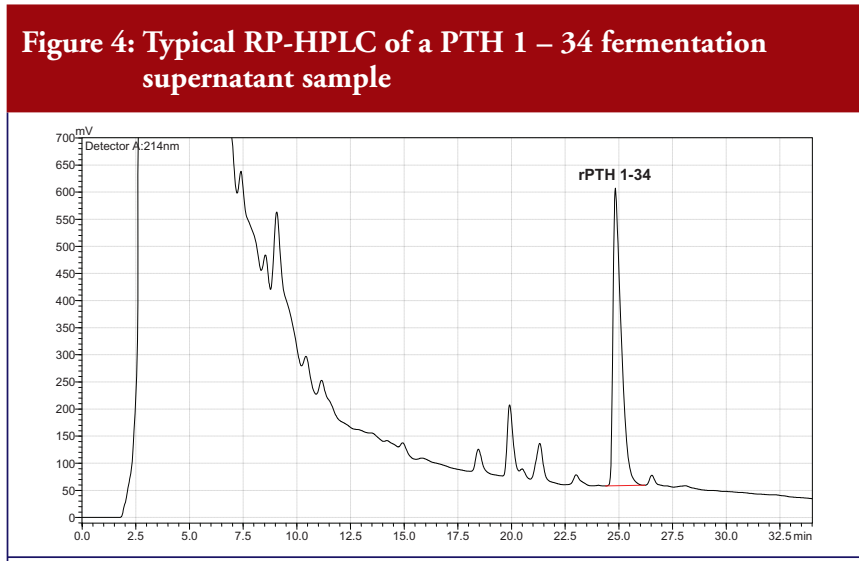

RP-HPLC profile from final supernatant of $80 \mathrm{~L}$ run, with a final concentration of $137 \mu \mathrm{g} / \mathrm{mL}$, showing main peak identified as rPTH 1-34 at retention time of 24.8 minutes. or acidification step to release the PTH product. Such processing steps not only requires the subsequent complete removal of the fusion protein partner and of the enzyme, if used, but also unfavorably adds to manufacturing costs. A clear advantage of our H. polymorpha expression system is that rPTH 1-34 is translated intact and exported as the correctly-folded active peptide without having first to ligate it to a secondary protein. Since rPTH 1-34 is also stably active following secretion into the fermentation medium, other processing steps such as unfolding or refolding of fusion proteins extracted from bacteria/E. coli, are avoided, see Table 3. By optimization of culture conditions in a stepwise fashion through scaling up of fermentation volumes, by almost five orders of magnitude to $80 \mathrm{~L}$, we were able to develop and implement a robust $\mathrm{rPTH} 1-34$ production protocol that led to high level secretion and yields of rPTH 1-34, comparable with those achieved by other systems, see Table 3 . Moreover, this secretion and accumulation of rPTH 1-34 in high concentration makes subsequent purification process steps relatively more straightforward than with fusion proteins, and which should lead to its more economical manufacture.

In summary, our study has provided strong proof that the methylotrophic yeast $H$. polymorpha can form the basis of an appropriately efficient expression and production system for the production and potential manufacture of active rPTH 1-34. Advantageously, and without the intervention of enzymatic cleaving of a fusion protein, active rPTH 1-34 is stably secreted into the fermentation supernatant. High yields, as much as $150 \mathrm{mg}$ rPTH 1-34/L, were attained by the development of high expressing, transformed $H$. polymorpha strains, the optimization of fermentation conditions and operations and the effective scaling up of the production process to high volume bioreactors. In comparison with other manufacturing approaches, our development of a simple, robust and reproducible fermentation protocol for large scale production of rPTH 1-34 potentially offers a more effective, cost saving, possibly superior method for its commercial manufacture.

\section{Acknowledgement}

We wish to deeply thank Dr Anthony Meager for his skillful and excellent assistance in language editing and valuable expert comments.

\section{Authors' contributions}

Ms Manal Moussa carried out the fermentation runs in small scale and medium scale. Ms Maria El Ghazaly carried out all analytical experiments except the potency test. Dr Jan Rohde participated and carried out a critical manuscript revision for important intellectual content. Ms Nicole Bartsch and Dr Antje Parthier contributed all fermentation runs at large scale and helped to draft the manuscript. Dr Frank Kensy carried out all experiments in the microliter scale in the BioLector system. Mr Frank Mueller has drafted and revised the manuscript. All authors read and approved the final manuscript.

Competing interests: Ms Nicole Bartsch and Dr Antje Parthier are employees at Scil Proteins in Halle, Dr Ing Frank Kensy is Managing Director at m2p-Labs in Baesweiler and Dr Jan Rohde, Ms Manal Moussa, Ms Maria El Ghazaly and Mr Frank Mueller are employees at Minapharm Pharmaceuticals. The authors have no conflicts of interests that are directly relevant to the content of this manuscript. 


\section{Table 3: Overview of current expression systems for recombinant parathyroid hormone (rPTH) variants}

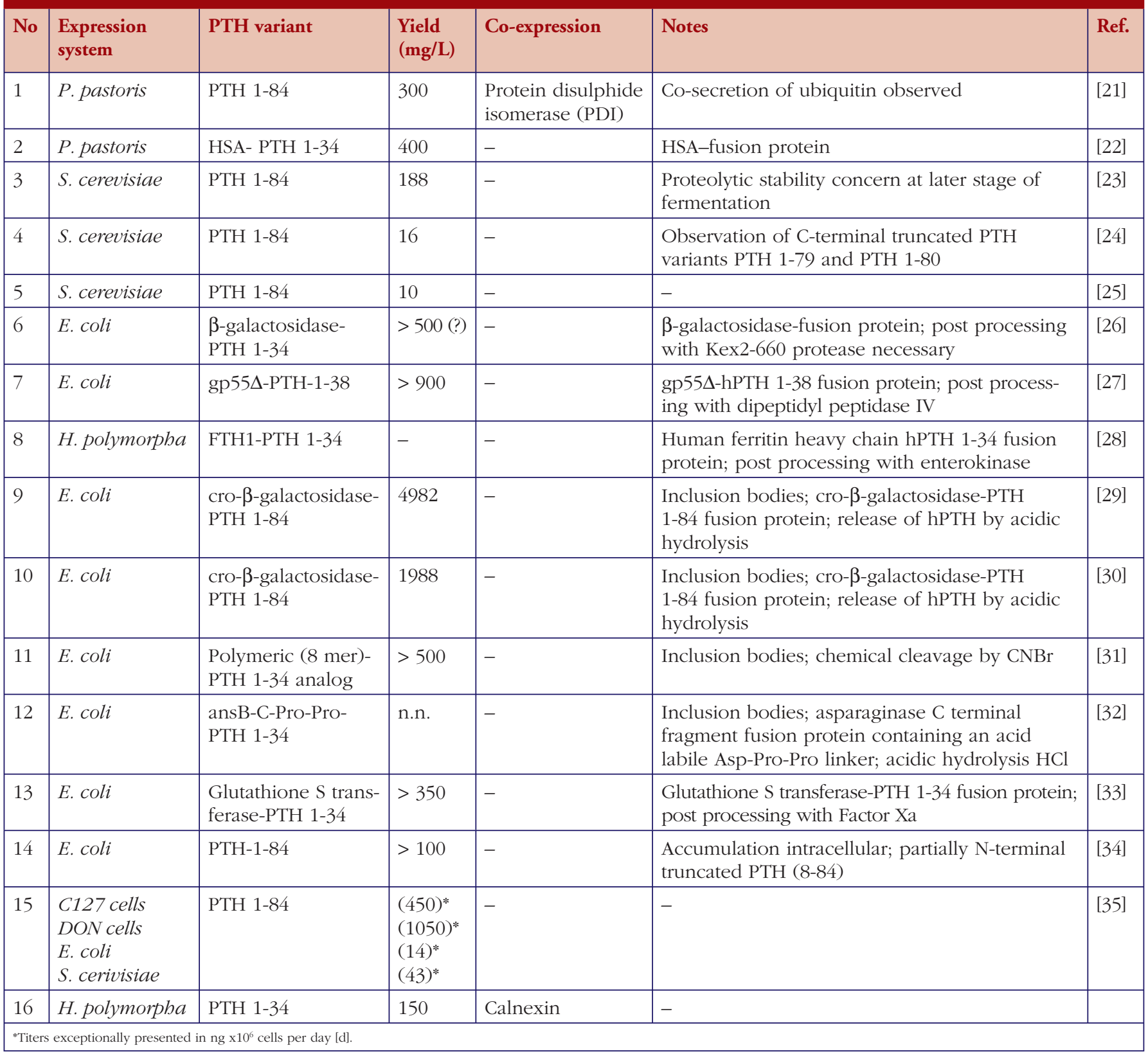

This research received no specific grant from any funding agency in the public, commercial, or not-for-profit sectors.

Provenance and peer review: Not commissioned; externally peer reviewed.

\section{Co-authors}

Manal Moussa, MSc, Minapharm Pharmaceuticals, Cairo, Egypt Maria El Ghazaly, MSc, Minapharm Pharmaceuticals, Cairo, Egypt Jan Rohde, PhD, Minapharm Pharmaceuticals, Cairo, Egypt Nicole Bartsch, MSc, Scil Proteins, Halle, Germany Antje Parthier, PhD, Scil Proteins, Halle, Germany Frank Kensy, Dr Ing, m2p-Labs, Baesweiler, Germany

\section{References}

1. Lane NE. Epidemiology, etiology and diagnosis of osteoporosis. Am J Obstet Gynecol. 2006;194:S3-11.

2. Whitaker M, Guo J, Kehoe T, Benson G. Bisphosphonates for osteoporosis where do we go from here? N Engl J Med. 2012;366(22):2048-51.

3. US Food and Drug Administration. Background document for meeting of Advisory Committee For Reproductive Health Drugs and Drug Safety and Risk Management Advisory Committee. 2013 [cited 2013 Jul 31]. Available from: http://www.fda.gov/downloads/AdvisoryCommittees/CommitteesMeeting Materials/Drugs/ReproductiveHealthDrugsAdvisoryCommittee/UCM341779. pdf

4. Baron R, Hesse E. Update on bone anabolics in osteoporosis treatment: rationale, current status, and perspectives. J Clin Endocrinol Metab. 2012;97(2):311-25. 
5. Borba VZC, Manas NCP. The use of PTH in the treatment of osteoporosis. Arq Bras Endocrinol Metabol. 2010;54(2):213-9.

6. Cusano NE, Costa AG, Silva BC, Bilezikian JP. Therapy of osteoporosis in men with teriparatide. J Osteoporos. 2011;2011:463675.

7. Shen L, Xie X, Su Y, Luo C, Zhang C, Zeng B. Parathyroid hormone versus bisphosphonate treatment on bone mineral density in osteoporosis therapy: a meta-analysis of randomized controlled trials. PLoS One. 2011;6(10):e26267.

8. Jin L, Briggs SL, Chandrasekhar S, Chirgadze NY, Clawson DK, Schevitz RW, et al. Crystal structure of human parathyroid hormone 1-34 at 0.9-A resolution. J Biol Chem. 2000;275(35):27238-44.

9. Verhaar HJJ, Lems WJ. PTH-analog: comparable or different. Arch Gerontol Geriatr. 2009;49(2):e130-2.

10. Hansenula polymorpha. In: Gellissen G, editors. Biology and application. Wiley-VCH Verlag GmbH; 2002. ISBN 3-527-30341-3.

11. Gellissen G, Kunze G, Gaillardin C, Cregg JM, Beradi E, Veenhuis M, et al. New yeast expression platforms based on methylotrophic Hansenula polymorpha and Pichia pastoris and on dimorphic Arxula adeninivorans and Yarrowia lipolytica一a comparison. FEMS Yeast Research. 2005;5(11):1079-96.

12. Stöckmann C, Scheidle M, Dittrich B, Merckelbach A, Hehmann G, Melmer G, et al. Process development in Hansenula polymorpha and Arxula adeninivorans, a re-assessment. Microb Cell Fact. 2009;8(22):1-10.

13. Klabunde J, Kleebank S, Piontek M, Hollenberg CP, Hellwig S, Degelmann A. Increase of calnexin gene dosage boosts the secretion of heterologous protein by Hansenula polymorpha. FEMS Yeast Res. 2007;7(7):1168-80.

14. Weydemann U, Keup P, Piontek M, Strasser AW, Schweden J, Gellissen G, Janowicz ZA. High-level secretion of hirudin by Hansenula polymorphaauthentic processing of three different preprohirudins. Appl Microbiol Biotechnol. 1995;44(3-4):377-85.

15. Sierkstra LN, Verbakel JMA, Verrips CT. Optimization of a host/vector system for heterologous gene expression by Hansenula polymorpha. Curr Genet. 1991;19(2):81-7.

16. Faber KN, Haima P, Harder W, Veenhuis M, AB G. Highly efficient electrotransformation of the yeast Hansenula polymorpha. Curr Genet. 1994;25(4):305-10.

17. Roggenkamp R, Hansen M, Eckart M, Janowicz Z, Hollenberg CP. Transformation of the methylotrophic yeast Hansenula polymorpha by autonomous replication and integration vectors. Mol Gen Genet. 1986;202(2):302-8.

18. Veenhuis M, Keizer I, Harder W. Characterization of peroxisomes in glucosegrown Hansenula polymorpha and their development after the transfer of cells into methanol-containing medium. Arch. Microbiol. 1979;120:167-75.

19. Schrag JD, Bergeron JM, Li Y, Borisova S, Hahn M, Thomas DY, et al. The structure of calnexin, an ER chaperone involved in quality control of protein folding. Mol Cell. 2001;8(3):633-44.

20. Conesa A, Jeenes D, Archer DB, van den Hondel CA, Punt PJ. Calnexin overexpression increases manganese peroxidase production in Aspergillus niger. Appl. Environ. Microbiol. 2002;68(2):846-51.

21. Vad R, Nafstad E, Dahl LA, Gabrielsen OS. Engineering of Pichia pastoris expression system for secretion of high amounts of intact human parathyroid hormone. J Biotechnol. 2005;116(3):251-60.
22. Chen J, Sun HY, Yang Y, Wang XF, Chen SQ. Construction, expression and characterization of recombinant fusion protein HSA-PTH (1-34) in Pichia pastoris. [Chinese]. Zhejiang Da Xue Xue Bao Yi Xue Ban. 2008;37(2): $126-33$.

23. Song GY, Chung BH. Overproduction of human parathyroid hormone by fed-batch culture of a Saccharomyces cerevisiae mutant lacking yeast aspartic protease 3. Process Biochemistry. 1999;35(5):503-8.

24. Vad R, Moe E, Saga K, Kvinnsland AMV, Øyen TB. High-level production of human parathyroid hormone (hPTH) by induced expression in Saccharomyces cerevisiae. Protein Expr Purif. 1998;13(3):396-402.

25. Gabrielsen OS, Reppe S, Sæther O, Blingsmo OR, Sletten K, Gordeladze JO, et al. Efficient secretion of human parathyroid hormone by Saccharomyces cerevisiae. Gene. 1990;90(2):255-62.

26. Suzuki Y, Yabuta M, Ohsuye K. High-level production of recombinant human parathyroid hormone 1-34. Appl Environ Microbiol. 1998;64(2):526-9.

27. Gram H, Ramage P, Memmert K, Gamse R, Kocher HP. A novel approach for high level production of a recombinant human parathyroid hormone fragment in Escherichia coli. Biotechnology (N Y). 1994;12(10): 1017-23.

28. Eilert E, Hollenberg CP, Piontek M, Suckow M. The use of highly expressed FTH1 as carrier protein for cytosolic targeting in Hansenula polymorpha. J Biotechnology. 2012;159(3):172-6.

29. Harder MP, Sanders EA, Wingender E, Deckwer WD. Studies on the production of human parathyroid hormone by recombinant Escherichia coli. Appl Microbiol Biotechnol. 1993;39(3):329-34.

30. Harder MP, Sanders EA, Wingender E, Deckwer WD. Production of human parathyroid hormone by recombinant Escherichia coli TG1 on synthetic medium. J Biotechnol. 1994;32(2):157-64.

31. Oldenburg KR, D'Orfani AL, Selick HE. A method for the high-level expression of a parathyroid hormone analog in Escherichia coli. Protein Expr Purif. 1994; $5(3): 278-84$.

32. Chunxiao W, Jingjing L, Yire X, Min D, Zhaohui W, Gaofu Q, et al. Study on preparation and activity of a novel recombinant human parathyroid hormone (1-34) analog with N-terminal Pro-Pro extension. Regul Pept. 2007; 141(1-3):35-43.

33. Gangireddy SR, Madhavi RD, Ravikanth KR, Reddy PK, Konda VR, Rao KRSS, et al. High yield expression of human recombinant PTH (1-34). Curr Trends Biotechnol Pharm. 2010;4(1):568-77.

34. Oshika Y, Yamada T, Nakagawa S, Fujishima A, Kawase M, Ishibashi Y, et al. Human parathyroid hormone: efficient synthesis in Escherichia coli using a synthetic gene, purification and characterization. Int J Pept Protein Res. 1994;43(5): $441-7$.

35. Rokkones E, Kareem BN, Olstad OK, Høgset A, Schenstrøm K, Hansson L, et al. Expression of human parathyroid hormone in mammalian cells, Escherichia coli and Saccharomyces cerevisiae. J Biotechnol. 1994;33(3): 293-306.

DOI: 10.5639/gabij.2013.0203.035

Copyright $\odot 2013$ Pro Pharma Communications International 